\title{
CHINA'S INTEGRATION INTO THE WORLD ECONOMY
}


This page is intentionally left blank 


\section{GHINA'S INTEGRATION INTO THE WORLD ECONOMY}

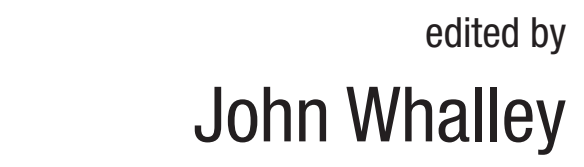

The University of Western Ontario, Canada 


\section{Published by}

World Scientific Publishing Co. Pte. Ltd.

5 Toh Tuck Link, Singapore 596224

USA office: 27 Warren Street, Suite 401-402, Hackensack, NJ 07601

UK office: 57 Shelton Street, Covent Garden, London WC2H 9HE

\section{British Library Cataloguing-in-Publication Data}

A catalogue record for this book is available from the British Library.

\section{CHINA'S INTEGRATION INTO THE WORLD ECONOMY}

Copyright (C 2011 by World Scientific Publishing Co. Pte. Ltd.

All rights reserved. This book, or parts thereof, may not be reproduced in any form or by any means, electronic or mechanical, including photocopying, recording or any information storage and retrieval system now known or to be invented, without written permission from the Publisher.

For photocopying of material in this volume, please pay a copying fee through the Copyright Clearance Center, Inc., 222 Rosewood Drive, Danvers, MA 01923, USA. In this case permission to photocopy is not required from the publisher.

ISBN-13 978-981-4304-78-8

ISBN-10 981-4304-78-6

Typeset by Stallion Press

Email: enquiries@stallionpress.com

Printed in Singapore. 


\section{ACKNOWLEDGEMENTS}

During the period of writing or co-writing these papers, I have been fortunate to have received financial and intellectual support from a number of sources. On the financial front, I have been greatly aided by the China Programme of the Centre for International Governance Innovation (CIGI), Waterloo, Ontario, as well as research grants from the Social Sciences and Humanities Research Council (SSHRC), and the Ontario Research Fund during the later stages of work on the volume. Discussion, comment and academic collegial input has come from many sources, including Shuming Zhang, Xin Xian, Li Shi, Yuezhou Cai, Tongsan Wang, Yu Yongding, Wang Li, Yiming Wang, Yao Li, Yan Dong, Huifang Tian. Logistical and organizational support has been provided by Kun Peng. To all, I am grateful. 
This page is intentionally left blank 


\section{INTRODUCTION}

This volume contains twelve papers that I have either authored or co-authored over the last six years dealing with China's integration into the world economy. This integration has been one of the most dramatic economic events since the period of the Second World War. Since the mid1970s, China has increased its real income per capita by approximately eight times. China has grown from having trade substantially smaller than that of Hong Kong back in the 1970s to a position today where China is the second largest trading country among all global traders. China accounts for nearly $50 \%$ of all inward foreign investment coming from the OECD. China has made tremendous progress in terms of poverty alleviation, with sharp reductions in the numbers of individuals and households below the poverty line, although this has been accompanied by a sharp increase in relative inequality particularly between urban and rural areas.

How all this has been accomplished is still a subject of substantial debate and difference of position in literature. There are those, such as Paul Krugman, who characterize Chinese growth as a triumph of perspiration over inspiration, emphasizing the role that physical capital accumulation has played in this process. However, more recent policy announcements in China attach great significance to the educational process in China, where there has been an enormous four-fold increase in the number of graduate and undergraduate students since the late 1990s and the generation of ideas, and the sharp growth which has taken place in China's trade in information technology products. These products now account for nearly $40 \%$ of China's exports, whereas back in the mid-1990s, they were perhaps no more than $2 \%$, with textiles and apparel being a much more prominent and important component of China's exports.

These controversies are central to this integration process. Insofar as the widely held belief in China has been that the major driver of China's growth has been its integration into the global economy, which accelerated greatly after 1992 with changes in policy structure and large inflows of 
foreign direct investment. Following this there was significant growth of exports, then with further elevation following China's successful accession to the WTO in 2001. In recent years, China's export growth had been running at nearly $30 \%$ per year, pre-financial crisis, but in the crisis fell sharply. There is also a belief in Chinese policy circles that accumulation of human capital and infrastructure development in China (roads, ports, telecomm, airports, etc.) have been as instrumental in the growth process as physical capital accumulation. As noted above, the contrast in view is notable with Western literature, which tends to emphasize physical capital accumulation.

The chapters in the volume which follow deal with various dimensions and aspects of this overall set of issues, arising with any assessment of the contribution into the global economy for its development. In the first part China's growth strategy, in light of the growing participation of the global economy, is discussed. The first paper deals with China's inward foreign direct investment and uses a decomposition of the Chinese economy into the Chinese FDI and non-FDI sectors and to assess how FDI flows relate to the sustainability of future Chinese growth. Using an extension of conventional single sector growth accounting, due to Solow, Dennison and others, this paper takes a two-sector approach and uses data classified on a FDI, non-FDI sectoral basis. Results suggest that the majority of China's growth is accounted for by FDI in the period from the early 1990s on, and that, in turn, a significant portion of China's technical progress is concentrated in the FDI portion of the economy. This suggests that if in the future, there is a plateauing or even a fall in FDI, this could significantly affect Chinese growth prospects. Foreign direct investment into China was already beginning to plateau in the period before the financial crisis and the crisis has taken its toll both on Chinese exports and on inward FDI, although China, seemingly, has been able to maintain a relatively high growth rate of 6-8\% through the financial crisis.

The second paper deals with technology upgrading as part of China's growth strategy out to 2020. It discusses and evaluates the eleventh 5-year plan, published in 2005 in China which emphasizes the need for China to move from export growth based on lower quality products such as textiles and apparel and into higher quality items such as electronics, machine tools, autos and engineering products. This 5 year plan sets out the whole strategy as to how this is to be accomplished: major increases in educational spending, R\&D tax credits, geographical zones which will promote these policies, large spending on mega-projects, and intellectual 
property arrangements which are designed both to protect new innovations that the Chinese produce, but also reduce dependency on expensive foreign intellectual property. All this is set out in the Chapter and an evaluation of this strategy proceeds, emphasizing many of the fundamental divisions which exist between Western and Chinese literature in terms of the determinants of Chinese growth processes.

The third paper in this section, presents both data on and forward projections of China's rapidly growing trade and investment flows with Southern countries. The South is defined to exclude Hong Kong (China), Korea and Singapore, large bilateral trade links for China. The data indicate that from a low base in the 1990's when Southern trade was growing more slowly than China's overall trade it subsequently grows rapidly. After 2001 (WTO accession) there is a significant acceleration, which pre crisis was in turn further accelerating. In 1995 Southern trade was $13 \%$ of China's total trade; but by 2007 it was $28 \%$ of China's total trade and growing at $42 \%$ per year on the export side in contrast to $26 \%$ for all exports. By country, India (with a 33-fold increase between 1995-2007) is the most rapidly growing bilateral partner, followed by Brazil (18 fold increase between 1995-2007). By region, Latin America and Africa are the largest regional sources of trade growth, with more dispersion across countries in Asia. Also, in contrast to its total trade, China runs a significant trade deficit in its Southern trade due to imports of resource products. We report projections that by 2015 Southern trade (assuming unchanged growth rates) would be over $50 \%$ of China's trade, and by 2025 India will account for over $50 \%$ of China's trade.

It also presents data on Southern and bilateral FDI flows involving China and developing countries. From a very small base in the 1990s, these are now growing at even more rapid rates than China's trade. Bilateral flows between India and China, for instance, grew 90-fold between 1995 and 2007.

Part two of the volume then goes on to discuss China's aid and trade policies. In Chapter 4 on China's new regional trade agreements, the emphasis is on the range, scope and form of these regional agreements, and how they emerged so quickly in the period following China's accession to the WTO in 2001. Unlike other large entities earlier acceding to the WTO, who remained strongly committed to multilateralism for several decades prior to entry into significant regional agreements, China's approach seems to be more pragmatic, with a combined multilateral and regional approach, beginning by way of initial agreements with Hong Kong and then spreading 
to agreements with Australia, New Zealand, ASEAN and Singapore, and elsewhere. Interestingly, these agreements are also very different in form one from another. They appear to dovetail with the interests of the bilateral negotiating participant, rather than following a common template structure as is common with the US and the EU. Increasingly in the years ahead, the expectation is that regional agreements of this form will grow in significance and scope for China, as China's trade policies take ever more centre stage in her developmental strategy.

Chapter 5 discusses liberalization in China's key service sectors following WTO accession, exploring some scenarios as to how this liberalization will play out and raising some issues of measurement. The key sectors involved are banking, insurance and telecoms. Interestingly, at the point of WTO accession by China in 2001, a major demand from OECD countries, particularly the US and EU, was for the unilateral liberalization by China in these key service sectors. The decision made by China to join the WTO with these commitments was the more broad ranging one of prioritizing engagement with the international community over insulation from global interactions rather than the precise details of what were to be involved.

China thus largely accepted the terms of accession in services as they were presented to them by the OECD countries through the WTO accession process. In the banking area, the commitments are breathtaking in scope. They involve China effectively moving to open international banking over the period out to 2008. This is to allow entry of foreign banks into branch banking in China, entry into banking using both domestic and foreign currencies, and with almost no restrictions on banking activities within China. The paper in the volume suggests that, if fully implemented as committed, China's banking system would be on par with banking activity in the Cayman Islands in terms of openness. The reality of banking liberalization however, has been far more limited in practice. There have been major changes in banking structure in China, but not change to the extent which these commitments would suggest. Changes in insurance arrangements are less dramatic, as they were relatively liberal towards foreign insurers before the accession negotiations. The issue had been much more the degree of uptake by foreign insurance companies, with opportunities in the Chinese market with few formal barriers to constrain them. In telecoms, the agreement focuses on the degree of foreign participation in and ownership of Chinese telecom operators and also access of those operators to the Chinese market. 
This section concludes with Chapter 6 discussing China's post-WTO accession trade stance. Prior to the completion of the lengthy negotiations on Chinese WTO accession, there was extensive debate inside China on the merits of this step from a Chinese perspective. This debate has continued despite the initiation of implementation of the terms of accession now due to be completed by 2007. The talk in China today is of post-WTO China; and every new policy initiative is discussed not only in terms of its WTO compatibility, but also in terms of its ability to contribute to the implementation of the accession process and the eventual harnessing of China's resulting WTO benefits. The completion of accession negotiations was been hailed internally as a milestone in China's economic development, with claims of significant additions to growth potential, and a new policy environment underpinned by the single most important policy departure since Deng Xiao Ping's introduction of the responsibility system in 1976. At the same time, WTO accession has been criticized by detractors as establishing too quickly a western-style market-oriented environment in China, which will likely lead to greater inequality and over-centralization, and has resulted in China giving away too many WTO bargaining chips which could have been more effectively used in later global negotiations.

There has been much discussion at the policy level of Chinese exchange rate policy in recent years of these issues, with repeated pressures from the US in particular for China to change its exchange rate policy, which is believed to be a source of both major accumulation of reserves and a source of artificial stimulus to Chinese export performance by maintaining export volumes at higher levels than would otherwise be the case.

This issue has always been difficult for economists to analyze using conventional models because traditional models of international trade are pure barter economies in which money is neutral and with a simple monetized extension, exchange rates have no effects. In such models trade is either balanced, or there is a fixed exogenous trade imbalance. This chapter therefore departs from previous literature by modeling the exchange rate regime in terms of a fixed exchange rate at which the Chinese central bank stands ready to accumulate foreign reserves at the fixed exchange rate, and as such, the trade imbalance is endogenously determined. Using this structure and calibrating to Chinese data from 2005, the model is able to be used to analyze numerically the impacts of the renminbi appreciation on the trade imbalance and welfare. In the simple static framework used, policies which reduce reserve accumulation and increase imports are welfare improving. 
Part three of the volume continues with a chapter discussing how China's tax policies are best designed under global integration. China's tax policy has been a surprisingly important component of Chinese policy in recent years. China is relatively highly taxed, with more than $30 \%$ of GDP flowing through the tax system. The value-added tax in particular has grown since its initial introduction in 1994 into a tax which accounts for nearly $40 \%$ of tax revenues. The enterprise tax has also undergone major change from effectively an accumulation of surpluses of state-owned enterprises to a formal enterprise tax with a clearly defined base and statutory rate and moving close to the corporate tax structure in use in the OECD, but with major tax incentives towards R\&D and investment.

The first of the chapters in this section deals with the Unified Enterprise Tax and the behavior of state-owned enterprises of China. In 1992, a key element in the changes in policy structure towards foreign investment, in this was to introduce a special tax regime for FDI, under which FDI and the income accruing to it were effectively taxed at around half the rate compared to income accruing to domestic enterprises. This is widely believed by some at the time to be one of the significant sources of stimulus for inward foreign investment, although by no means necessarily the only or dominant source. However, these elements of tax structure were seen in 1992 as only a temporary arrangement, pending a move to a unified tax. The movement to the unified tax took place in 2006, with legislation which removed these tax preferences over a four year period out to 2010.

This chapter uses modeling techniques to analyze the impact of these tax changes. It suggests that if conventional competitive models are used to analyze such tax changes, then they will be viewed as desirable on the grounds that they remove a distortion. But, once the differential structure of state owned relative to private enterprises is taken into account, things change. Different prototype models of SOE are used where, representative of the earlier Iron Rice bowl period, enterprise managers are treated as politically appointed and receiving credits from the state banking system in ways such that any losses are automatically recapitalized. In such a world, if managers try to maximize their personal network or guanxi, then they would maximize the size of the enterprise, effectively hiring labor up to the point where the wage paid to labour is equal to the average product of labor rather than the marginal product. In such a world, the numerical modeling reported on in this chapter shows that the move to a unified enterprise tax is no longer so clearly welfare-improving, and under some circumstances may even be welfare-worsening. 
A second chapter in this section evaluates the Chinese Value Added Tax (VAT) in its current impure form relative to a pure form using a monetary trade model similar in structure to that used in the chapter on China's renminbi appreciation. The impurities in the Chinese VAT stem from two separate sources. The first relates to the export rebates which are common in all VATs throughout the world but are different in China. China's experience with export rebates was one of rapid growth of both exports and revenue losses. In 1994, when the tax was introduced, the value of rebates which were claimed far exceeded the budgetary revenues available to finance such rebates. So rebates were initially frozen for a few years and were then reintroduced at rates which were significantly lower that the statutory rate when the VAT was introduced. As such, a completely separate system of rebates on exports came to coexist with the rest of the VAT regime. This is atypical compared to VAT regimes from around the world. In addition, the VAT in China has, since 1994, operated on an income basis rather than a consumption basis, (again unusual) in which the expensing of capital goods is not allowed. This chapter evaluates these features and emphasizes how, in a model such as the renminbi appreciation model where there is an endogenous trade surplus. Features of tax structure which tend to retard exports can be welfare-improving because they reduce the size of the trade surplus, which in turn, reflects the exchange of goods on the one hand and paper, which is non-contributive to utility in static models, on the other. Thus this impure form of VAT, which in the conventional model used in most public finance analysis would be welfare inferior compared to the pure form, turns out to be welfare-improving.

The volume then continues with a fourth part on China and global architecture. The first Chapter in this part discusses Chinese activity in Africa. China's large and growing presence in Africa, which has become especially prominent in the last two to three years, is now the subject of substantial curiosity and even puzzlement outside of China. The focus of this curiosity is primarily Sub-Saharan Africa, where the majority of this activity is concentrated. While for now still small relative to China's reserves and overall trade, it is nonetheless sizable relative to current resource flows into Africa. As a source of development finance to Africa, if this involvement continues to grow, China will in a few years be poised to outrank combined financial flows from multilateral agencies (the World Bank, the IMF) and private in-flows from OECD countries. Trade between China and Africa is growing at rates in the order of $30 \%$ per year, from an admittedly low base. FDI inflows to Africa from China are growing at similar rates. 
The African Development Bank now has its annual meetings not in Africa, but in Shanghai. The elevation of mean growth rates in Sub-Saharan Africa from around $4.5 \%$ to $6-6.5 \%$ in the last two years can in part be linked to the growing Chinese presence in Africa. Chinese enterprises are centrally involved in Africa in resources, textiles and apparel, construction, finance, and many other fields. Seemingly, everywhere one looks in Africa, one finds present or recent Chinese activity. This charter documents this phenomenon and explore the factors which underlie it.

Chapter 10 discusses post-MFA performance of developing Asia, and China in particular, noting that with the termination of the Multi-Fibre Arrangement (MFA) in 2005 under the WTO agreement on textiles in the Uruguay Round in 1994, major changes took place in the structure of global production and trade which significantly influenced China. It had been anticipated that there would be a large surge in China's exports of textiles and apparel following MFA removal. This discusses the size, and dimensions, and geographical composition of this surge and the policy reponse outside of China. The surges which occurred reflected many years of pent-up supply and generated new China containment trade measures, which came into place driven by protectionist pressures in the EU and the US and spread elsewhere including into the developing world (Brazil and Peni for example). How and why this occurred is set out in Chapter 10.

Chapter 11 is in the final part of the volume dealing with China and inequality which has grown substantially over the period of China's global engagement. China has made major progress dealing with absolute poverty and numbers below poverty lines have fallen. But relative inequality has widened. Here, emphasis is on the contributing factors to inequality in China in recent years and the sources of growth of relative inequality. One of the important factors has been the hukou system of labor mobility restrictions between urban and rural areas, under which significant portions of the population in rural areas have been constrained in terms of their ability to move into other areas. It has rather been through temporary migrant workers that migration has taken place, and many typically return to their villages within 3-4 years after their migration. This policy structure has generates a segmentation of labor markets within China, and in this chapter using calibrated models and data from 2005, numerical simulation methods are used to evaluate the impact on inequality of these mobility restrictions. This is done in a variety of models of increasing complexity, including models of form in which the dampening effect of increased house prices generated by migration surges into rural areas also come into play. 
The conclusion is that hukou restrictions have been a significant factor in restraining migration which in turn would lessen relative inequality.

The volume concludes with a chapter which focuses on volatility of incomes in rural areas and its contribution to inequality in China. It is often argued that because of rural income volatility that inequality is in some sense a less serious problem in China than is perceived because over a period of time, people will move above and below the poverty line threshold and so the numbers of people who are permanently below the line is smaller than might appear in annual poverty related data.

This paper argues an opposite position which suggests that in the presence of inequality, one has to account for the presence of volatility and account for it in terms of its impact on expected income. Thus an increase in volatility in rural incomes reduces the certainty equivalence of income, and therefore increases overall inequality. This analysis uses data from the Chinese Household Income Panel, collected by Li Shi and others at the Chinese Academy of Social Sciences to analyze this issue.

All these papers contribute in one way or another to debate on China's participation in the global economy. How important has it been for China's strong growth performance? How should that engagement proceed given the special elements of China's economic structure? How sustainable is this strategy for growth in the medium to long run? These issues will remain central to China's future developmental strategy for decades to come and especially after the current financial crisis. 
This page is intentionally left blank 


\section{CONTENTS}

Acknowledgements $\quad \mathrm{v}$

Introduction vii

Part 1: FDI and Technology 1

Chapter 1: China and FDI 3

Chapter 2: Technology Upgrading and China's Growth

Strategy to 2020

Chapter 3: China's Rapidly Changing Trade and Investment $\begin{array}{ll}\text { Involvement with the South } & 73\end{array}$

$\begin{array}{ll}\text { Part 2: China's Trade Policies } & 97\end{array}$

Chapter 4: China's New Regional Trade Agreements 99

Chapter 5: China in the World Trading System 123

Chapter 6: China's Post-Accession WTO Stance 155

$\begin{array}{ll}\text { Part 3: China's Tax System } & 177\end{array}$

Chapter 7: The Unified Enterprise Tax and SOEs in China 179

Chapter 8: Evaluating the Impure Chinese VAT Relative

to a Pure Form in a Simple Monetary Trade Model with an Endogenous Trade Surplus

Part 4: China in the World

Chapter 9: China's Growing Economic Activity in Africa

Chapter 10: The Post MFA Performance of Developing Asia 
Part 5: Chinese Enterprises and Labour Mobility

Chapter 11: A Numerical Simulation Analysis of (Hukou) Labour Mobility Restrictions in China

Chapter 12: Chinese Experience with Global 3G Standard-Setting

Chapter 13: State-Owned Enterprise Behavioural Responses to Trade Reforms: Some Analytics and Numerical Simulation Results Using Chinese Data

Index 